\title{
Evaluasi Stabilitas Lereng Pada Tubuh Bendungan Butak, Kabupaten Grobogan, Provinsi Jawa Tengah
}

\author{
Adi Setya Yudha Pratama ${ }^{1 *}$, Najib Najib ${ }^{1}$, Devina Trisnawati ${ }^{1}$ \\ ${ }^{1}$ Departemen Teknik Geologi Fakultas Teknik Universitas Diponegoro, Semarang
}

\begin{abstract}
Abstrak
Bendungan Butak yang terletak di Desa Butak, Kecamatan Kradenan, Kabupaten Grobogan, Provinsi Jawa Tengah merupakan salah satu bangunan air dengan tipe bendungan homogen. Fungsi utama dari bendungan ini ialah sebagai sarana irigasi dengan luas daerah aliran $160 \mathrm{~km}^{2}$. Mengingat urgensinya, suatu bendungan dapat dikategorikan tingkat bahayanya berdasarkan hasil evaluasi stabilitas lereng bendungan. Upaya ini dapat dilakukan dengan menganalisis faktor keamanan (Fk) bendungan. Penelitian ini bertujuan untuk mengetahui nilai faktor keamanan (Fk) pada tubuh Bendungan Butak. Metode yang digunakan adalah metode observasi dan metode analisis data secara kuantitatif meliputi pemetaan geologi, pemetaan geoteknik, hasil pengeboran inti, dan uji laboratorium mekanika tanah dari contoh tanah tidak terganggu dengan uji soil test berikut uji triaxial $U U$ serta perhitungan koefisien beban gempa terkoreksi OBE dan MDE. Hasil penelitian dari penyelidikan pemetaan permukaan diperoleh satuan endapan aluvium dengan persebaran lempung dan lanau berada di sekitar bendungan. Hasil penyelidikan bawah permukaan dengan 4 lubang bor terdiri dari tanah lempung. Parameter desain Bendungan Butak meliputi berat isi basah $(\gamma)$, kohesi (c), sudut geser dalam $(\phi)$, dan garis freatik muka air bendungan, serta beban gempa terkoreksi (Ko) digunakan untuk memperoleh nilai faktor keamanan (Fk) menggunakan perangkat lunak Slide V6.009 dengan metode Bishop. Hasil analisis pada 14 kondisi dari muka air maksimum diperoleh hasil Fk hitung $>1,2 \mathrm{Fk}$ minimum , muka air normal dengan hasil Fk hitung $>1,1 \mathrm{Fk}$ minimum, dan muka air surut cepat didapatkan hasil Fk hitung $>1,3 \mathrm{Fk}$ minimum, sehingga Bendungan Butak dikategorikan memenuhi syarat keamanan dari standar Fk minimum yang ditetapkan oleh SNI 8064;2016.
\end{abstract}

Kata kunci: Bendungan Butak, stabilitas lereng, faktor keamanan (Fk).

\begin{abstract}
Butak Dam which located in Butak Village, Kradenan District, Grobogan Regency, Central Java Province is one type of homogeneous dam. The main function of this dam is as an irrigation facility with a flow area of $160 \mathrm{~km}^{2}$. Given its urgency, a dam can be categorized as a hazard based on the results of the stability evaluation of the dam slope. This effort can be done by analyzing the safety factor (Sf) of the dam. This study aims to determine the value of the safety factor (Sf) on the body of the Butak Dam. The method used is the method of observation and method of quantitative data analysis including geological mapping, geotechnical mapping, core drilling results, and soil mechanics laboratory tests from samples of undisturbed soil with soil test following triaxial UU test and calculation of OBE and $M D E$ corrected earthquake load coefficients. The results of the investigation of the surface mapping were obtained by alluvium deposits with the distribution of clay and silt around the dam. The results of the subsurface investigation with 4 bore holes consist of clay soil. By obtaining Butak Dam design parameters including wet content weight $(\gamma)$, cohesion (c), inner shear angle $(\phi)$, and phreatic level of the dam water level, and corrected earthquake load (Ko) is used to obtain the value of the safety factor (Sf) using Slide V6.009 software with Bishop method. The results of the analysis on 14 conditions of the maximum water level obtained results of Sf count $>1.2$ Sf minimum, normal water level with the results of Sf count > 1.1 Sf minimum, and fast low tide faces obtained Sf count> $1.3 \mathrm{Sf}$ minimum, so that the Butak Dam is categorized safety as the requirements of the minimum Sf standard set by SNI $8064 ; 2016$.
\end{abstract}

Keywords: Butak Dam, slope stability, safety factor (Sf).

*) Korespondensi: Adi_Setya_Yudha_Pratama@yahoo.com 


\section{PENDAHULUAN}

Kabupaten Grobogan merupakan salah satu wilayah penggerak sektor agraria di Provinsi Jawa Tengah dengan jumlah penduduk $\pm 1,4$ juta jiwa. Kebutuhan akan ketersediaan air sangat vital dan harus dimanajemen dengan baik salah satunya dengan pemanfaatan ketika musim penghujan. Oleh karena itu, perlu dilakukan usaha-usaha untuk menampung air saat musim hujan dalam sebuah tampungan raksasa berupa bendungan. Menurut Peraturan Pemerintah Nomor 37 Pasal 1 Tahun 2010 tentang bendungan, bahwa bendungan adalah bangunan yang berupa urugan tanah, urugan batu, beton, dan pasangan batu yang dibangun untuk menahan dan menampung air, dapat pula dibangun untuk menahan dan menampung limbah tambang (tailing), atau menampung lumpur sehingga terbentuk waduk.

Selain aspek positif manfaat bendungan harus dipertimbangkan faktor keamanan terhadap pengaruh kestabilan lereng bendungan. Hal ini harus menjadi perhatian khusus guna meminimalkan dampak negatif yang ditimbulkan baik materi dan korban jiwa. Diantaranya terjadi keruntuhan atau longsoran bendungan akibat beban melampaui volume tampungan, amblasan, dan banjir bandang. Sehingga perlu adanya evaluasi yang menyeluruh dan berkala kestabilan lereng bendungan secara komprehensif.

Kestabilan lereng suatu bendungan merupakan salah satu persyaratan yang harus dipenuhi dalam suatu bendungan, dimana jika syarat kestabilan lereng tersebut tidak terpenuhi, maka bisa mengakibatkan masalah keamanan bendungan yang meliputi retakan, rembesan, dan longsoran. Kestabilan lereng ini dipengaruhi oleh banyak faktor, antara lain material tubuh bendungan, kemiringan tubuh bendungan, gelombang air atau beban gempa dan lain-lain (Fredlund dan Rahardjo, 1993). Penelitian di Bendungan Butak, Kabupaten Grobogan, Provinsi Jawa Tengah dilakukan untuk mengetahui tingkat faktor keamanan (Fk) kestabilan lereng pada bendungan yang diteliti sesuai Standar Nasional Indonesia (SNI) 8064: 2016.

\section{Penyelidikan Geoteknik}

Penyelidikan geoteknik terdiri atas dua jenis penyelidikan itu penyelidikan permukaan dan penyelidikan bawah permukaan. Adapun penjelasannya berikut.
1. Penyelidikan permukaan bertujuan untuk menjelaskan kondisi geologi di permukaan dengan lengkap dengan cara melakukan pemetaan pada daerah yang sedang diteliti. Penyelidikan ini terdiri dari pemetaan geologi dan pemetaan geoteknik (Sosrodarsono dan Takeda, 1981).

2. Penyelidikan bawah permukaan diperlukan contoh (sampel) batuan untuk identifikasi, klasifikasi, pemeriksaan di lapangan maupun uji di laboratorium. Sampel batuan yang diambil harus mewakili lapisan batuan yang dijumpai karena sampel yang tidak mewakili akan menghasilkan kesimpulan yang salah mengenai kondisi bawah permukaan (Seed dan Idriss, 1971). Penyelidikan bawah permukaan dilakukan dengan pengeboran inti menggunakan single tube core barrrel untuk memperoleh sampel batuan termasuk didalamnya sampel Undisturbed Sample (UDS) berikut pengujian Standart Penetration Test (SPT) di lapangan.

\section{Uji Laboratorium Mekanika Tanah}

Pengujian laboratorium yang dilakukan bertujuan untuk memperoleh data dan informasi parameter sifat fisik maupun sifat mekanika tanah, selanjutnya parameter tersebut akan digunakan sebagai bahan analisis dan pertimbangan perencanaan serta desain tipe penanganan longsoran.

Pengujian ini mencakup pengujian soil test meliputi nilai kandungan air pada tanah atau batuan, berat isi tanah kering atau basah, dan specific gravity (Ameratunga dkk., 2016) dan uji triaxial unconsolidated undrained (UU).

\section{Tipe Bendungan Urugan}

Bendungan merupakan bangunan yang berfungsi menampung air hujan untuk dipergunakan sebagai air baku, irigasi, air bersih, dan sebagainya (Soedibyo, 1993). Suatu bendungan yang dibangun dengan cara menimbunkan bahanbahan seperti batu, kerikil, pasir dan tanah pada komposisi tertentu dengan fungsi sebagai pengangkat permukaan air yang terdapat di dalam bendungan disebut bendungan tipe urugan (Soedibyo, 1993). Bendungan pada penelitian ini termasuk dalam kategori tipe bendungan urugan homogen. 


\section{Analisis Kegempaan}

Chopra (1995) menyebutkan bahwa gempa bumi adalah suatu peristiwa alam dimana terjadi getaran pada permukaan bumi akibat adanya pelepasan energi secara tiba-tiba dari pusat gempa. Metode analisis gempa yang digunakan untuk merencanakan bangunan tahan gempa dapat diklasifikasikan menjadi dua, yaitu analisis statik dan analisis dinamik (Chopra, 1995).

Analisis kegempaan ini dilakukan dalam beberapa tahap.

1. Klasifikasi kelas beban bendungan.

2. Kelas risiko bendungan.

3. Kriteria beban bendungan

4. Koefisien gempa terkoreksi bendungan.

\section{Stabilitas Lereng Tubuh Bendungan}

Penentukan kestabilan lereng identik dengan faktor keamanan (Fk), yang merupakan perbandingan antara gaya-gaya yang menahan, terhadap gaya-gaya yang menggerakkan tanah tersebut. Dalam penelitian ini untuk menentukan faktor keamanan menggunakan Metode Bishop. Metode ini sangat cocok digunakan untuk pencarian secara otomatis bidang runtuh kritis yang berbentuk busur lingkaran untuk mencari faktor keamanan minimum selain memberikan hasil perhitungan faktor keamanan yang cukup teliti.

Metode Bishop dapat dicari dengan mengetahui berat segmen tanah (W), kohesi tanah (cb), sudut antara bidang horisontal dengan garis kerja kohesi $(\theta)$, sudut geser dalam $(\varnothing)$, dan kemiringan lereng $(\beta)$ dengan persamaan sebagai berikut:

$$
F k=\frac{1}{\sum W \cdot \sin \theta} \sum \frac{\{c b+W(1-\mu \beta) \tan \emptyset\} \sec \theta}{1+\frac{\tan \theta \tan \emptyset}{F k}} \ldots \ldots
$$

Perhitungan metode bishop ini menggunakan software Slide V6.009 guna menentukan faktor keamanan (Fk) dari paramter desain yang dibuat.

\section{Spesifikasi Bendungan}

Bendungan Butak dengan spesifikasi teknis oleh Balai Pengelolaan Sumber Daya Air (BPSDA) Serang Lusi Juana (2016), yaitu :
1. Tahun Konstruksi : 1901
2. Elevasi Puncak $: 69,60 \mathrm{~m}$
3. Elevasi Bendungan $: 27,3^{\circ}$
4. Tinggi Bendungan $: 5,63 \mathrm{~m}$
5. Lebar Puncak
$: 4,00 \mathrm{~m}$
6. Panjang puncak
: $235,00 \mathrm{~m}$
7. MA Normal
: 4,061 m
8. MA Maksimum
: 4,732 m
9. Volume Normal
$: 1,60$ juta $\mathrm{m}^{3}$

\section{METODOLOGI}

\section{Metode Observasi Lapangan}

Metode ini dimulai dengan pembahasan awal mengenai studi literatur tentang kestabilan lereng bendungan yang dilanjutkan dengan pengumpulan data sekunder seperti peta topografi, peta geologi regional, peta rupa bumi Indonesia (RBI) dan peta zona gempa indonesia untuk mencari ataupun mengambil data yang berada di permukaan bumi. Setelah studi literatur dan data sekunder lengkap, kemudian dilakukan survei dan penyelidikan di lokasi penelitian.

\section{Metode Analisis}

Metode analisis meliputi pengambilan data primer yaitu pemetaan geologi, geoteknik, dan pemboran inti. Hasil pemetaan geologi dan pemetaan geoteknik di peroleh peta geomorfologi, peta aliran sungai, dan peta geologi serta dan peta geoteknik. Adapun hasil pengeboran inti bertujuan untuk mencari data yang terdapat di dalam permukaan bumi yaitu dengan cara mengambil sampel batuan pada kedalaman tertentu untuk selanjutnya dilakukan uji laboratorium. Uji laboratorium yaitu uji soil test dan uji triaxial. Hasil uji laboratorium yang diperoleh berupa besaran sudut geser dalam $(\varnothing)$, kohesi (c), dan berat isi $(\gamma)$ selanjutnya akan dijadikan parameter desain berikut analisis kegempaan (Ko) serta kondisi muka air bendungan. Perhitungan dan permodelan analisis stabilitas lereng bendungan menggunakan software Slide V6.009.

\section{HASIL}

\section{Litologi Daerah Penelitian}

Lokasi daerah penelitian terletak di Bendungan Butak, Kecamatan Kradenan, Kabupaten Grobogan, Provinsi Jawa Tengah dengan pada dengan luas dimensi pemetaan $1,5 \mathrm{~km} \times 1,5 \mathrm{~km}$. Daerah penelitian ini berada pada Satuan Endapan Aluvium (Qa) yang tersusun dari lempung dan lanau. Profil bendungan yang menunjukkan keberadaan dua material tersebut ditunjukkan pada Gambar 2. 


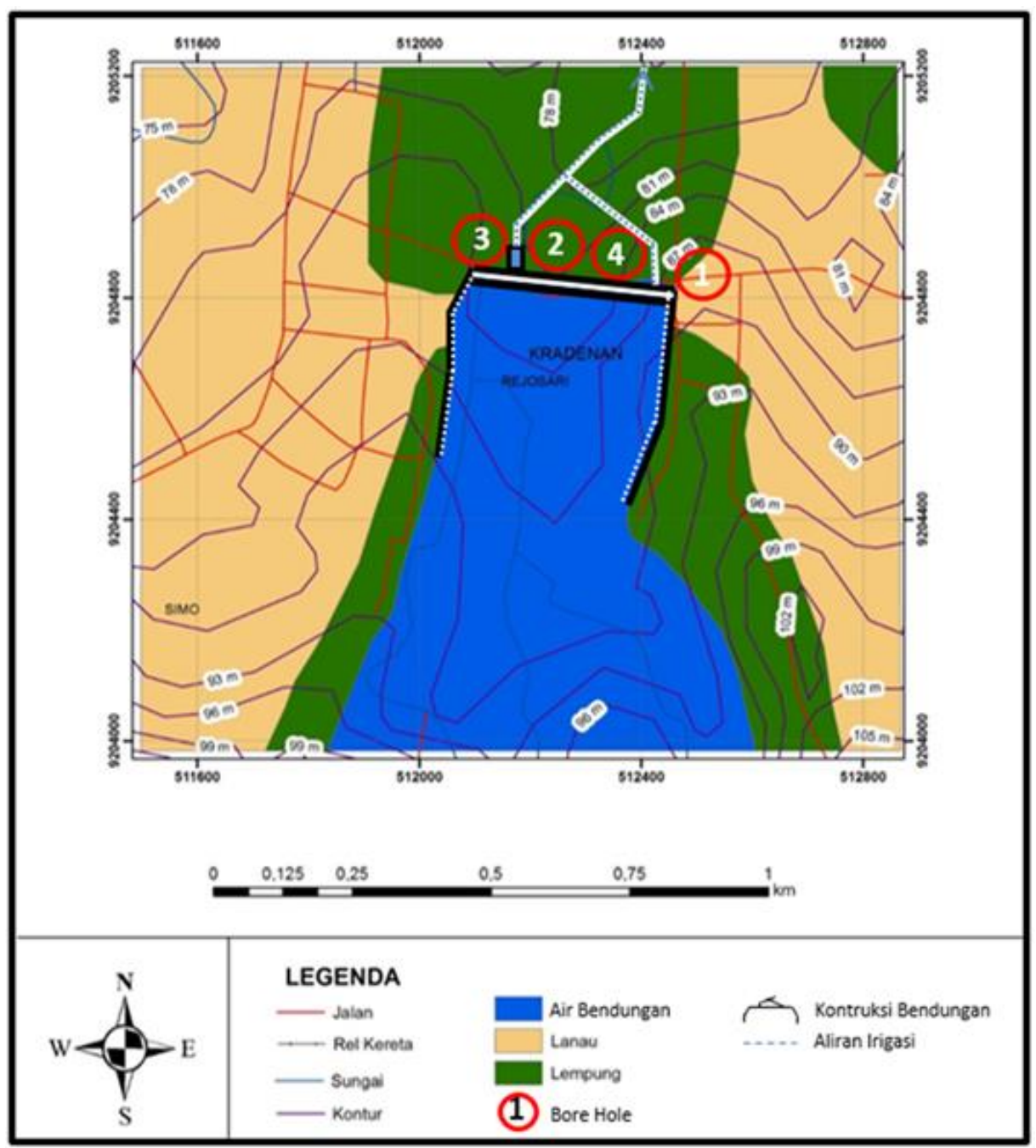

Gambar 1. Peta Geoteknik Bendungan Butak dan Sekitarnya.

Tabel 1. Hasil penyelidikan bawah permukaan

\begin{tabular}{|c|c|c|c|c|}
\hline No & No. Bor & $\begin{array}{c}\text { Kedalaman } \\
(\mathrm{m})\end{array}$ & $\begin{array}{l}\text { Nilai } \\
\text { N-SPT }\end{array}$ & Jenis Tanah \\
\hline \multirow[t]{4}{*}{1} & BH - 1 & $0,00-2,00$ & 9 & Lempung, warna kuning kehitaman, kaku \\
\hline & & $2,00-3,50$ & 14 & Lempung, warna kuning keputihan, kaku \\
\hline & & $3,50-5,00$ & 15 & Lempung, warna kuning keputihan, kaku \\
\hline & & $5,00-7,00$ & 12 & Lempung, warna kuning keputihan, kaku \\
\hline \multirow[t]{6}{*}{2} & BH - 2 & $0,00-2,00$ & 7 & Lempung, warna kuning kehitaman, teguh \\
\hline & & $2,00-3,50$ & 7 & Lempung, warna kuning kehitaman, teguh \\
\hline & & $3,50-5,00$ & 7 & Lempung, warna abu-abu, teguh \\
\hline & & $5,00-6,50$ & 8 & Lempung, warna hitam, teguh sampai kaku \\
\hline & & $6,50-8,00$ & 8 & Lempung, warna hitam, teguh sampai kaku \\
\hline & & $8,00-10,00$ & 9 & Lempung, warna hitam, teguh sampai kaku \\
\hline 3 & BH - 3 & $0,00-2,60$ & 4 & Lempung, warna kuning, teguh \\
\hline & & $2,60-3,50$ & 5 & Lempung, warna hitam, teguh \\
\hline & & $3,50-5,00$ & 5 & Lempung, warna abu-abu, teguh \\
\hline & & $5,00-7,00$ & 9 & Lempung, warna abu-abu, teguh \\
\hline \multirow[t]{4}{*}{4} & BH - 4 & $0,00-2,00$ & 7 & Lempung, warna kuning, teguh \\
\hline & & $2,00-3,50$ & 6 & Lempung, warna kuning, teguh \\
\hline & & $3,50-5,00$ & 5 & Lempung, warna abu-abu, teguh \\
\hline & & $5,00-7,00$ & 6 & Lempung, warna abu-abu, teguh \\
\hline
\end{tabular}


a. Lempung

Pengamatan secara megaskopis warna dari material berukuran lempung ialah hitam kecoklatan. Ukuran material lempung ini sangat halus $(0,002 \mathrm{~mm})$ dan termasuk semen non-karbonatan pada. Kebanyakan material lempung yang tersingkap di daerah penelitian telah mengalami pelapukan.
Lempung tersebut memiliki persebaran sebesar $40 \%$ di daerah penelitian dibandingkan tanah atau batuan lainnya. Lempung ini berada cenderung pada sungaisungai kecil dan areal persawahan dengan daerah yang jaraknya relatif sangat dekat dengan bendungan di Desa Butak dan di Desa Pakis.
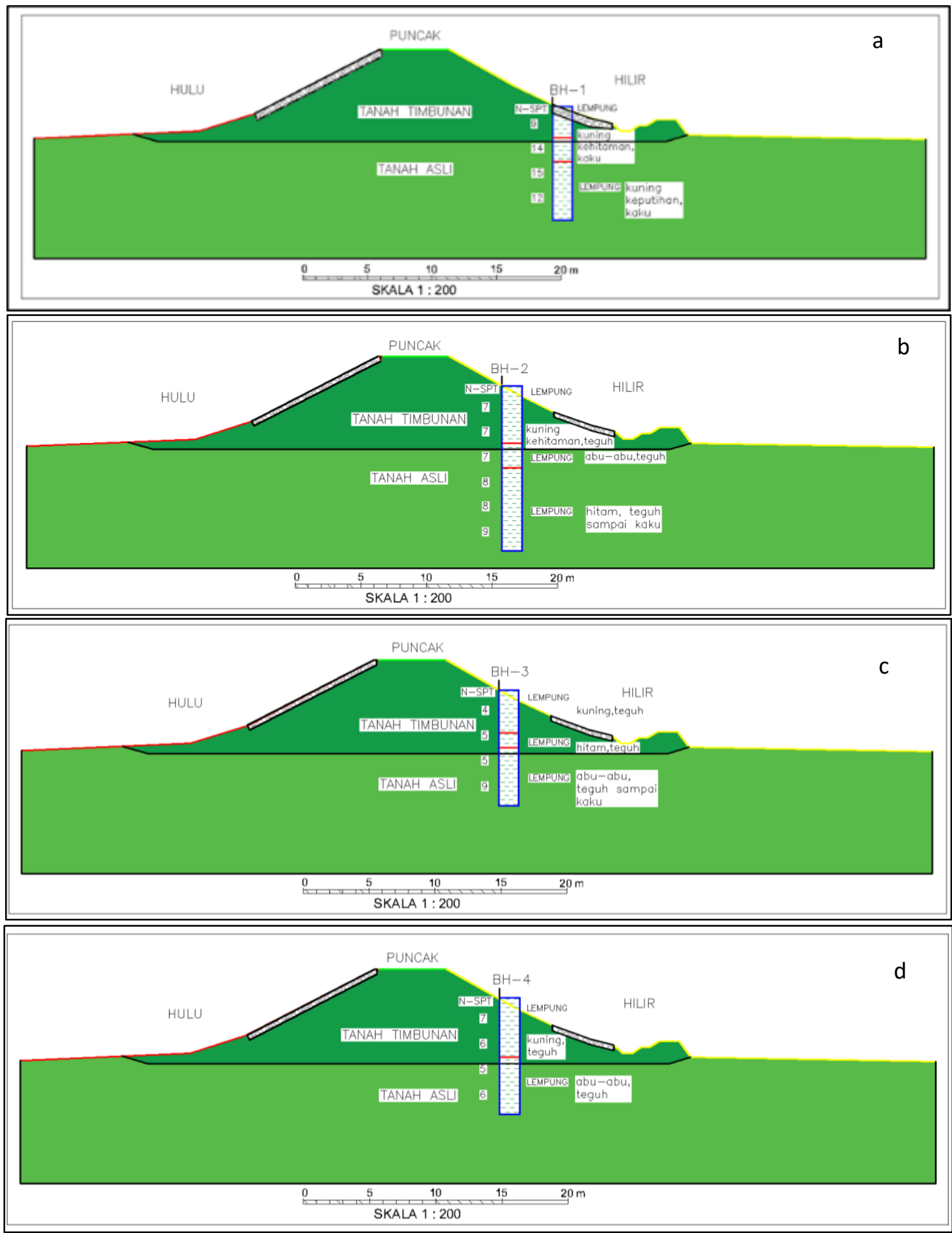

Gambar 2. Potongan melintang tubuh bendungan (a) BH-1, (b) BH-2, (c) BH-3, dan (d) BH-4. 
Tebal lapisan lempung ini tidak dapat ditentukan pasti dikarenakan persebarannya disesuaikan kontur permukaan.

b. Lanau

Material berukuran lanau diamati secara megaskopis memiliki warna coklatan keabuabuan. Ukuran butir material lanau lebih besar dibandingkan lempung dan terasa mengkasar jika disentuh $(0,002-0,06 \mathrm{~mm})$ dan termasuk semen non-karbonatan.

Lanau ini persebarannya $60 \%$ dibandingkan lempung. Lanau ini tersebar cenderung pada areal perkebunan dan daerah tinggian yang dekat dengan pemukiman warga di Desa Pakis dan di Desa Rejosari sekitar Bendungan Butak. Tebal lapisan lanau ini tidak dapat ditentukan pasti dikarenakan persebarannya disesuaikan kontur permukaan di sekitar daerah penelitian.

\section{Pengeboran Inti}

Penentuan titik pengeboran inti atau mesin Bendungan Butak dilakukan pada bagian hilir yang berada di puncak tubuh bendungan bagian timur sebanyak empat titik. Pengeboran inti bertujuan untuk menggambarkan kondisi bawah permukaan bendungan tersebut secara khusus dan dapat mengetahui lapisan tanah atau batuan yang terdapat di Bendungan Butak di Kabupaten Grobogan. Proses pengeboran ini menggunakan single tube core barrel. Pengeboran ini memiliki kedalaman bervariasi 7 meter pada $\mathrm{BH}-1, \mathrm{BH}-3$, dan $\mathrm{BH}-4$ serta 10 meter pada BH-2. Hasil dari pengeboran inti atau mesin Bendungan Butak yang dilakukan pada bagian hilir pada Tabel.1.

\section{Korelasi Hasil Pengeboran Inti}

Hasil pengeboran inti yang dilakukan pada titik $\mathrm{BH}-1, \mathrm{BH}-2, \mathrm{BH}-3$, dan $\mathrm{BH}-4$ menggunakan software Rockworks16 dilakukan analisis hubungan antar lapisan tanah atau batuan yang ada di bawah permukaan secara 2 dimensi maupun 3 dimensi. Korelasi antar 4 bore hole menggambarkan ketebalan dan persebaran batuan di bawah permukaan ditunjukkan pada Gambar 3 dan 4.

\section{Faktor Risiko Bendungan}

Adapun parameter yang digunakan diperoleh dari Balai Pengelolaan Sumber Daya Air Serang Lusi Juana (2016) pada Bendungan Butak, yaitu :

1. Kapasitas bendungan $: 264.000 \mathrm{~m}^{3}$

2. Tinggi bendungan $: 5$ meter

3. Kebutuhan evakuasi $: 0-300$

4. Tingkat kerusakan hilir : Moderat

Selanjutnya Dari hasil masing-masing parameter ini ditentukan angka pembobotan empat faktor risiko yang didapat maka ditentukan kelas risiko yang dihitung dari faktor risiko total (FRtot). Hasil perhitungan FRtot disajikan dalam Tabel 2 yang dikategorikan ke dalam kelas risiko II (Moderat) seperti yang ditunjukkan pada Tabel 3.

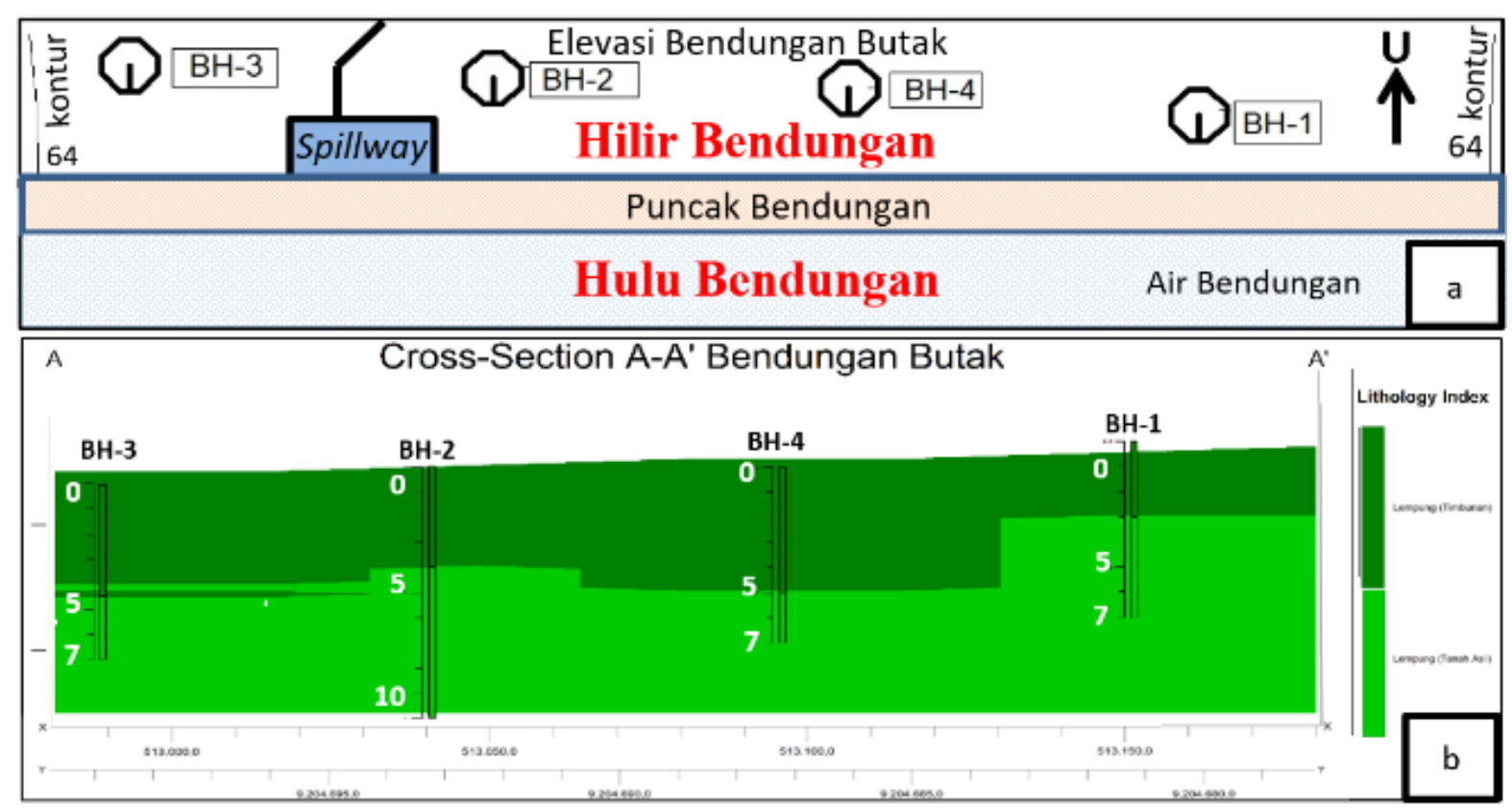

Gambar 3. Hasil korelasi 2 dimensi. (a) elevasi BH dan (b) penampang vertikal. 


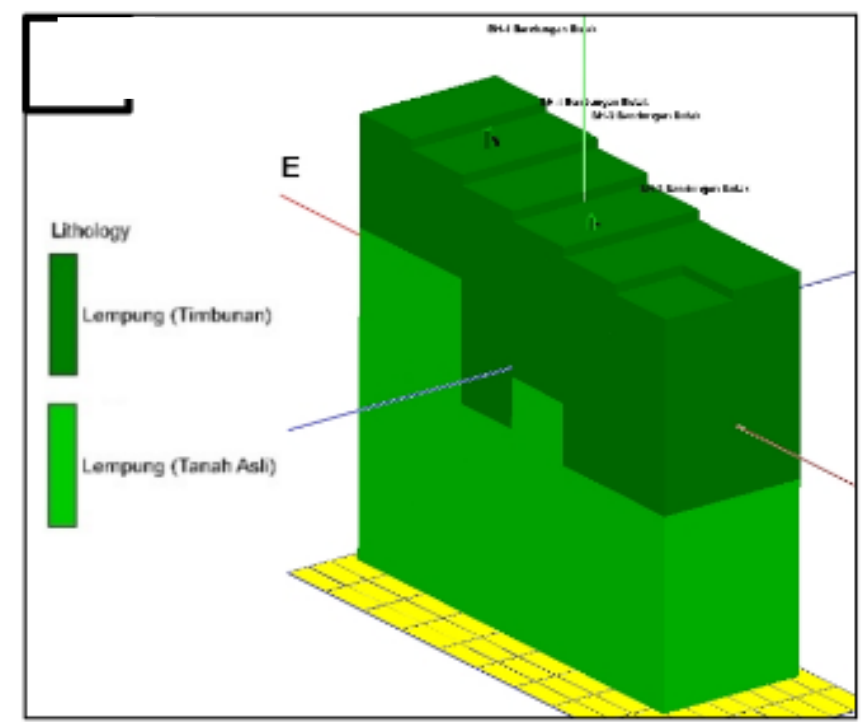

Gambar 4. (a) Hasil permodelan penampang 3 dimensi dan

Tabel 2. Faktor risiko (Pd T-14-2014-A)

\begin{tabular}{lcc}
\hline \multicolumn{2}{c}{ Faktor risiko } & Angka bobot \\
\hline Kapasitas Bendungan & $\left(\mathrm{FR}_{\mathrm{k}}\right)$ & 2 \\
Tinggi Bendungan & $\left(\mathrm{FR}_{\mathrm{t}}\right)$ & 0 \\
Kebutuhan Evakuasi & $\left(\mathrm{FR}_{\mathrm{e}}\right)$ & 8 \\
Tingkat Kerusakan Hilir $\left(\mathrm{FR}_{\mathrm{h}}\right)$ & 4 \\
\hline Faktor Risiko Total & $(\mathrm{FRtot})$ & 14 \\
\hline
\end{tabular}

Tabel 3. Kelas risiko (Pd T-14-2014-A)

\begin{tabular}{ll}
\hline \multicolumn{1}{c}{ Faktor risiko total } & \multicolumn{1}{c}{ Kelas risiko } \\
\hline$(0-6)$ & I (Rendah) \\
\hline$(7-18)$ & II (Moderat) \\
\hline$(19-30)$ & III (Tinggi) \\
$(31-36)$ & IV (Ekstrem) \\
\hline
\end{tabular}

Tabel 4. Kriteria beban gempa (Pd T-14-2014-A)

\begin{tabular}{|c|c|c|c|c|}
\hline \multirow{2}{*}{$\begin{array}{c}\text { Kelas risiko } \\
\text { dengan masa guna }\end{array}$} & \multicolumn{2}{|c|}{$\begin{array}{l}\text { Persyaratan tanpa } \\
\text { kerusakan }\end{array}$} & \multicolumn{2}{|c|}{$\begin{array}{l}\text { Persyaratan diperkenankan ada } \\
\text { kerusakan tanpa keruntuhan }\end{array}$} \\
\hline & $\begin{array}{c}\mathrm{T} \\
\text { (tahun) }\end{array}$ & $\begin{array}{l}\text { Metode } \\
\text { Analisis }\end{array}$ & $\begin{array}{c}\mathrm{T} \\
\text { (tahun) }\end{array}$ & $\begin{array}{l}\text { Metode } \\
\text { Analisis }\end{array}$ \\
\hline $\begin{aligned} & \text { IV } \\
= & 50-100\end{aligned}$ & $\begin{array}{c}100-200 \\
A_{d} \geq 0,1 \mathrm{~g}\end{array}$ & Koef Gempa & $\begin{array}{l}10.000 \\
\text { (MDE) }\end{array}$ & $\begin{array}{c}\text { Koef. gempa atau } \\
\text { dinamik * }\end{array}$ \\
\hline III & $\begin{array}{c}50-100 \\
A_{d} \geq 0,1 \mathrm{~g}\end{array}$ & Koef Gempa & $\begin{array}{l}5000 \\
(\mathrm{MDE})\end{array}$ & $\begin{array}{l}\text { Koef. gempa atau } \\
\text { dinamik * }\end{array}$ \\
\hline $\begin{array}{c}\text { II } \\
\mathrm{N}=50-100\end{array}$ & $\begin{array}{c}50-100 \\
A_{d} \geq 0,1 \mathrm{~g}\end{array}$ & Koef Gempa & $\begin{array}{l}3000 \\
(\mathrm{MDE})\end{array}$ & $\begin{array}{l}\text { Koef. gempa atau } \\
\text { dinamik * }\end{array}$ \\
\hline $\begin{array}{c}1 \\
N=50-100\end{array}$ & $\begin{array}{c}50-100 \\
A_{d} \geq 0,1 \mathrm{~g}\end{array}$ & Koef Gempa & $\begin{array}{l}1000 \\
(\mathrm{MDE})\end{array}$ & $\begin{array}{l}\text { Koet. gempa atau } \\
\text { dinamik * }\end{array}$ \\
\hline
\end{tabular}

Tabel 5. Parameter desain bendungan

\begin{tabular}{lcccc}
\hline Material & $\begin{array}{c}\text { Berat } \\
\mathbf{I s i} \\
\left(\mathbf{k N} / \mathbf{m}^{\mathbf{3}}\right)\end{array}$ & $\begin{array}{c}\text { Kohesi } \\
\left(\mathbf{k N} / \mathbf{m}^{2}\right)\end{array}$ & $\begin{array}{c}\text { Sudut } \\
\mathbf{G e s e r} \\
\text { Dalam }\left({ }^{\circ}\right)\end{array}$ & $\begin{array}{c}\text { Sumber } \\
\text { Data }\end{array}$ \\
\hline Timbunan & 16 & 30 & 5 & $\begin{array}{c}\mathrm{Uji} \\
\mathrm{Lab}\end{array}$ \\
Tanah asli & 17 & 15 & 21,7 & $\begin{array}{c}\mathrm{Uji} \\
\mathrm{Lab}\end{array}$ \\
& & & & $\mathrm{SNI}$ \\
Rip-Rap & 20 & 0 & 40 & $\mathrm{SNI}$ \\
$\begin{array}{l}\text { Beton } \\
\text { pelapis }\end{array}$ & 20 & 200 & 40 & $\mathrm{SNI}$ \\
\hline
\end{tabular}

Area yang termasuk ke dalam kelas risiko II memiliki kriteria yang ditunjukkan pada Tabel 4 . Hasil perhitungan koefisien gempa terkoreksi (Ko) baik pada periode ulang 100 tahun (OBE) dengan nilai $\mathrm{Ko}=0.06122449$ dan periode ulang 3.000 tahun (MDE) dengan nilai Ko = 0.21428571 digunakan untuk parameter pembuatan model.

\section{Analisis Stablilitas Lereng}

Nilai parameter desain material yang diperoleh untuk pengolahan software Slide V6.009 disajikan dalam Tabel 5. Hasil perhitungan koefisien gempa terkoreksi Analisis ini Analisis dan Interpretasi Faktor Keamanan (Fk) Kestabilan Lereng di lereng hulu dan hilir dengan beton pelapis dan tanpa beton pelapis :

1. Muka air normal tanpa beban gempa.

2. Muka air normal dengan beban gempa OBE (Gambar 5) dan MDE.

3. Muka air maksimum tanpa beban gempa.

4. Muka air maksimum dengan beban gempa OBE dan MDE (Gambar 6).

5. Muka air surut cepat dari normal ke minimum tanpa beban gempa (Gambar 7).

\section{A. Kondisi Muka Air Nomal}

Linsey dan Franzini (1991), mendefinisikan muka air normal adalah elevasi maksimum yang dicapai oleh kenaikan permukaan air waduk pada kondisi operasi biasa, dan genangan normal ditentukan oleh elevasi mercu pelimpah atau puncak pintu pelimpah (spillway). 


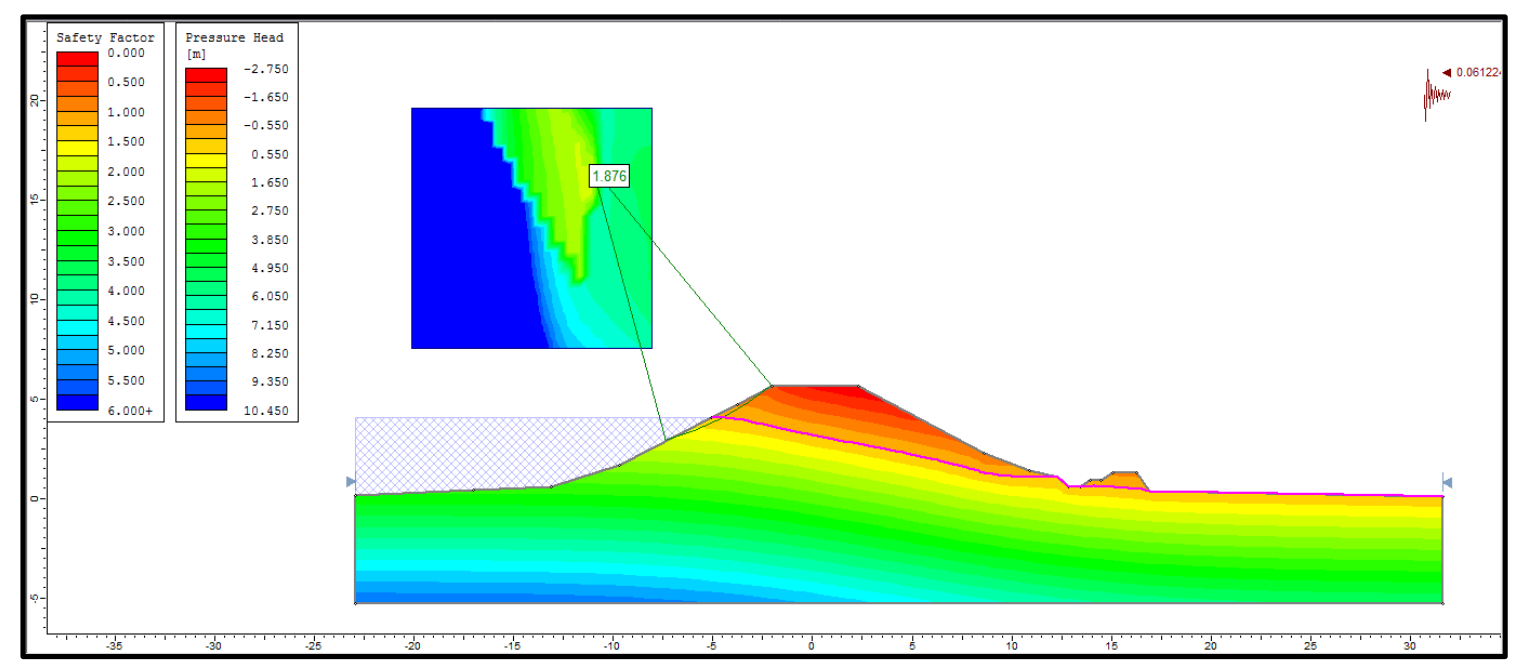

Gambar 5. Hasil analisis kestabilan lereng kondisi bendungan muka air normal dengan beban gempa OBE bagian hulu dengan nilai Fk ialah 1,876.

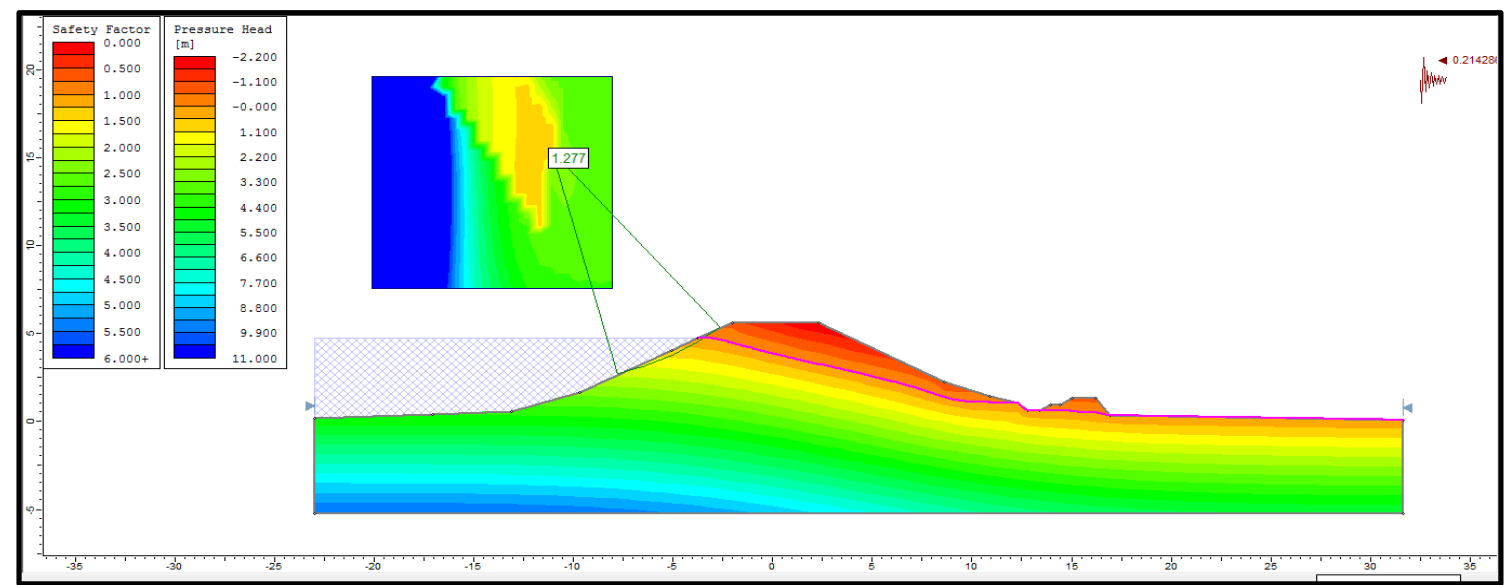

Gambar 6. Hasil analisis kestabilan lereng kondisi bendungan muka air maksimum dengan beban gempa MDE bagian hulu dengan nilai Fk ialah 1,277.

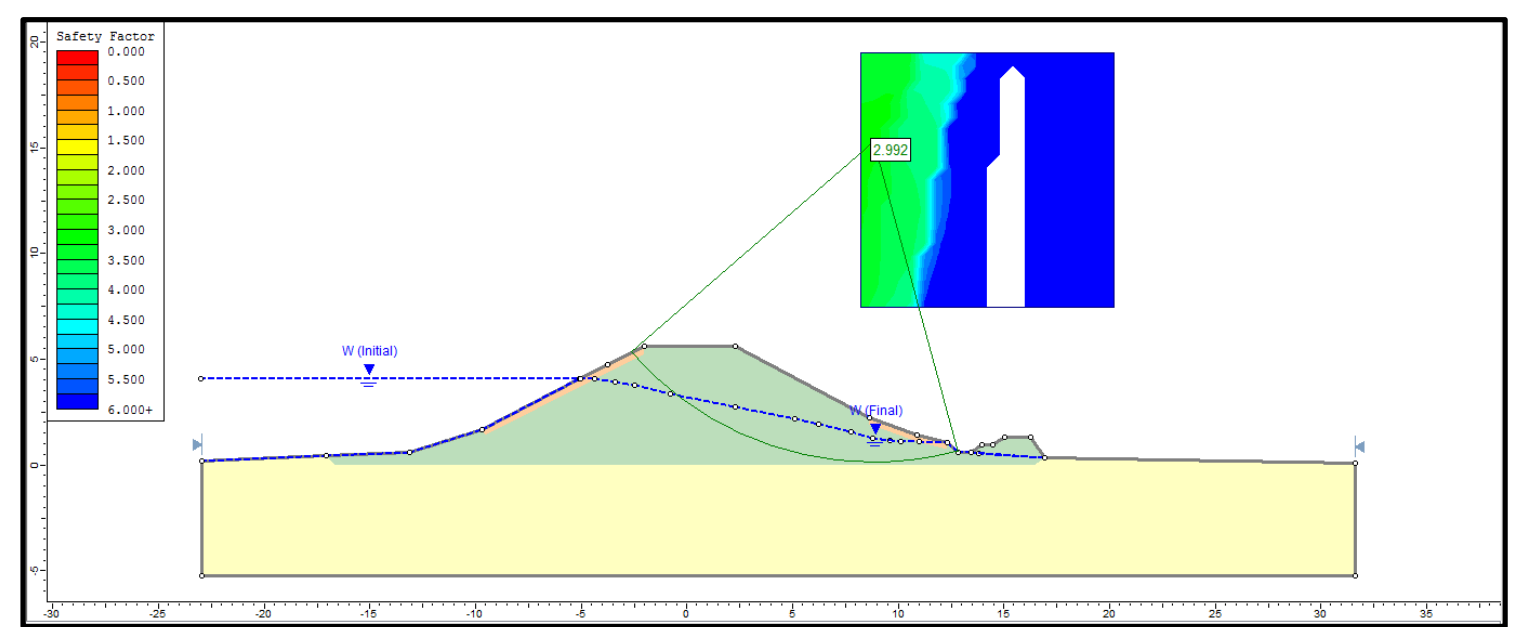

Gambar 7. Hasil analisis kestabilan lereng kondisi bendungan muka air surut cepat tanpa beban gempa bagian hilir dengan nilai Fk ialah 2,476. 
Muka air normal ini terletak pada elevasi 65,53 mdpl dengan memiliki garis freatik dengan ketinggian 4,061 meter dari dasar bendungan dilakukan permodelan software Slide V6.009 (Lampiran).

Penentuan faktor keamanan (Fk) ini dilakukan tanpa beban gempa bendungan dan beban gempa terkoreksi (Ko) dari hasil perhitungan OBE dan MDE baik di hulu maupun di hilir bendungan sesuai parameter desain pada Tabel 5 .

\section{B. Kondisi Muka Air Maksimum}

Penentuan elevasi muka air pada bendungan berkaitan dengan elevasi sungai tertinggi dan elevasi sungai terendah. Setelah menganalisis tampang bendungan, kemudian dapat diperoleh elevasi mercu bendungan. Selanjutnya dapat dihitung kontrol muka air di hulu dan di hilir bendungan (Soewarno, 1995).

Muka air maksimum ini terletak pada elevasi 64,86 mdpl dengan memiliki garis freatik dengan ketinggian 4,732 meter dari dasar bendungan untuk dilakukan input dalam permodelan software Slide V6.009 (Lampiran).

Penentuan faktor keamanan (Fk) ini dilakukan tanpa beban gempa bendungan dan beban gempa terkoreksi (Ko) dari hasil perhitungan OBE dan MDE baik di hulu maupun di hilir bendungan sesuai parameter desain pada Tabel 5.

\section{Kondisi Muka Air Surut Cepat}

Kondisi muka air surut cepat merujuk pada elevasi muka air bendungan yang mengalami penurunan secara cepat dan tibatiba dari kondisi muka air normal ke muka air minimum. Pada kondisi ini terjadinya penurunan signifikan daripada aliran air pori dari rongga-rongga butiran tanah, maka akan terjadi ketidakseimbangan tekanan air pori.

Muka air surut cepat ini terletak pada elevasi 65,53 mdpl dengan memiliki garis freatik dengan ketinggian 4,061 meter mulamula muka air normal ke muka air minimum dari dasar bendungan untuk dilakukan input dalam permodelan software Slide V6.009 (Lampiran).

\section{PEMBAHASAN}

\section{Evaluasi Analisis Stabilitas Lereng Bendungan}

Hasil analisis yang telah didapatkan angka faktor keamanan pada berbagai macam kondisi dengan pengolahan software Slide V6.009, digunakan untuk menentukan keamanan atau tidaknya suatu bendungan. Faktor keamanan minimum merujuk pada angka yang telah ditetapkan oleh SNI 8064:2016 (analisis stabilitas lereng bendungan tipe urugan) pada masing-masing kondisi.

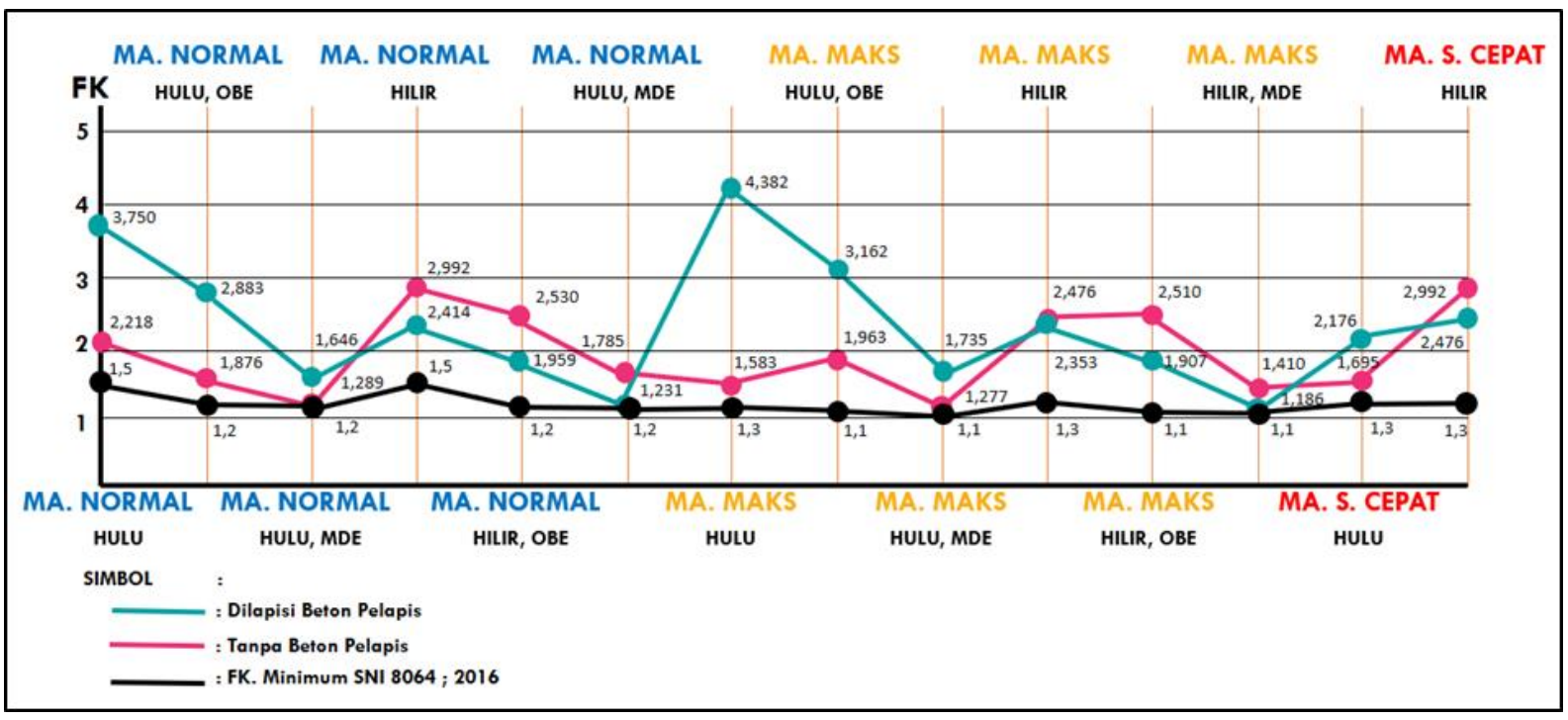

Gambar 5. Plotting nilai hasil Faktor Keamanan, berdasarkan angka keamanan minimum SNI 8064:2016. 
Tabel 6. Hasil analisis nilai Faktor Keamanan.

\begin{tabular}{|c|c|c|c|c|c|}
\hline \multirow[b]{2}{*}{ No } & \multirow[b]{2}{*}{ Kondisi Bendungan } & \multicolumn{2}{|c|}{ Angka Keamanan } & \multirow[b]{2}{*}{$\begin{array}{l}\text { Angka } \\
\text { Keamanan } \\
(\mathrm{SNI})^{*}\end{array}$} & \multirow[b]{2}{*}{ Keterangan } \\
\hline & & $\begin{array}{l}\text { Tanpa } \\
\text { Beton } \\
\text { Pelapis }\end{array}$ & $\begin{array}{l}\text { Beton } \\
\text { Pelapis }\end{array}$ & & \\
\hline 1 & $\begin{array}{l}\text { Bendungan muka air normal } \\
\text { tanpa beban gempa bagian hulu }\end{array}$ & 2,218 & 3,750 & 1,5 & Memenuhi \\
\hline 2 & $\begin{array}{l}\text { Bendungan muka air normal } \\
\text { dengan beban gempa OBE } \\
\text { bagian hulu }\end{array}$ & 1,876 & 2,833 & 1,2 & Memenuhi \\
\hline 3 & $\begin{array}{l}\text { Bendungan muka air normal } \\
\text { dengan beban gempa } \mathrm{MDE} \\
\text { bagian hulu }\end{array}$ & 1,289 & 1,646 & 1,2 & Memenuhi \\
\hline 4 & $\begin{array}{l}\text { Bendungan muka air normal } \\
\text { tanpa beban gempa bagian hilir }\end{array}$ & 2,992 & 2,414 & 1,5 & Memenuhi \\
\hline 5 & $\begin{array}{l}\text { Bendungan muka air normal } \\
\text { dengan beban gempa OBE } \\
\text { bagian hilir }\end{array}$ & 2,530 & 1,959 & 1,2 & Memenuhi \\
\hline 6 & $\begin{array}{l}\text { Bendungan muka air normal } \\
\text { dengan beban gempa MDE } \\
\text { bagian hilir }\end{array}$ & 1,785 & 1,231 & 1,2 & Memenuhi \\
\hline 7 & $\begin{array}{l}\text { Bendungan muka air maksimal } \\
\text { tanpa beban gempa bagian hulu }\end{array}$ & 1,583 & 4,382 & 1,3 & Memenuhi \\
\hline 8 & $\begin{array}{l}\text { Bendungan muka air maksimal } \\
\text { dengan beban gempa OBE } \\
\text { bagian hulu }\end{array}$ & 1,963 & 3,162 & 1,1 & Memenuhi \\
\hline 9 & $\begin{array}{l}\text { Bendungan muka air maksimal } \\
\text { dengan beban gempa MDE } \\
\text { bagian hulu }\end{array}$ & 1,277 & 1,735 & 1,1 & Memenuhi \\
\hline $\begin{array}{l}10 \\
11\end{array}$ & $\begin{array}{l}\text { Bendungan muka air maksimal } \\
\text { tanpa beban gempa bagian hilir } \\
\text { Bendungan muka air maksimal }\end{array}$ & 2,476 & 2,353 & 1,3 & Memenuhi \\
\hline & $\begin{array}{l}\text { dengan beban gempa } \mathrm{OBE} \\
\text { bagian hilir }\end{array}$ & 2,510 & 1,907 & 1,1 & Memenuhi \\
\hline 12 & $\begin{array}{l}\text { Bendungan muka air maksimal } \\
\text { dengan beban gempa MDE } \\
\text { bagian hilir }\end{array}$ & 1,410 & 1,186 & 1,1 & Memenuhi \\
\hline 13 & $\begin{array}{l}\text { Bendungan penurunan muka air } \\
\text { surut cepat dari normal ke muka } \\
\text { air minimum bagian hulu }\end{array}$ & 1,695 & 2,176 & 1,3 & Memenuhi \\
\hline 14 & $\begin{array}{l}\text { Bendungan penurunan muka air } \\
\text { surut cepat dari normal ke muka } \\
\text { air minimum bagian hilir }\end{array}$ & 2,992 & 2,476 & 1,3 & Memenuhi \\
\hline
\end{tabular}

Hasil Perhitungan faktor keamanan dapat dilihat pada Tabel 6 dan disajikan dalam bentuk grafik (Gambar 5), menunjukkan besaran nilai Fk masing-masing kondisi yang ditetapkan dengan pembagian klasifikasi berdasarkan urutan warna berbeda.

Hasil analisis dilakukan dalam 14 kondisi bendungan untuk dibandingkan faktor keamanan (Fk) minimum yang ditetapkan sesuai SNI 8064;2016 dengan warna dasar hitam pada tabel. 6. Berdasarkan hasil analisis yang diperoleh di 14 kondisi memiliki nilai faktor keamanan lebih besar dari standar minimal yang ditetapkan oleh faktor keamanan minimum (SNI). Dari semua kondisi dinyatakan Bendungan Butak memiliki stabilitas yang baik dan meskipun keruntuhan lereng dapat terjadi kapanpun dengan nilai faktor keamanan cukup kecil dengan zona kritis.

\section{KESIMPULAN}

Permukaan daerah Bendungan Butak seluruhnya terdiri dari satuan endapan aluvium (Qa) yang tersusun oleh lempung dan lanau, lempung pada timbunan berada di kedalaman 0,0-5,0 m memiliki NSPT 5-15 (teguh sampai kaku) dan tanah asli di kedalaman 5,0-10,0 m memiliki NSPT 6-12 (teguh sampai kaku). Hasil faktor keamanan (Fk) dari 14 kondisi, semua memiliki nilai faktor keamanan lebih besar dari standar minimal yang ditetapkan oleh faktor keamanan minimum SNI 8064:2016. Dari semua kondisi dinyatakan Bendungan Butak memiliki stabilitas yang baik meskipun terdapat beberapa zona kritis.

Secara spesifik dari penggunaan parameter menggunakan beton pelapis di bagian hilir harus dikaji ulang dalam pengaplikasiannya. Hal ini dikarenakan memperkecil faktor keamanan (Fk) beban gempa mengalami penurunan signifikan yang akan berdampak pada penurunan kestabilan bendungan itu sendiri dan mengakibatkan zona kritis dengan nilai faktor keamanan cukup kecil. Rekomendasi di bagian hulu agar bangunan beton pelapis dapat diganti dengan media seperti 
penutup kedap berbahan seperti aspal agar lebih ringan mengurangi pembebanan pada tubuh bendungan dan perlu penelitian lebih lanjut. Di sisi lain pengalokasian anggaran biaya pengeluaran lebih dimaksimalkan untuk perawatan bendungan secara berkala.

\section{UCAPAN TERIMA KASIH}

Penulis mengucapkan terima kasih kepada PT. Selimut Bumi Adhi Cipta yang telah mengeluarkan izin pemakaian data lapangan Bendungan Butak untuk penulisan karya tulis ini.

\section{DAFTAR PUSTAKA}

Ameratung, J., Sivakugan, N. dan Das, B.M., 2016. Correlations of Soil Rock Properties in Geothechnical Engineering. Springer: India.

Chopra, A.K., 1995. Dynamics of Structures (Theory and Applications to Earthquake Engineering). Prentice-Hall: New Jersey.

Fredlund, D.G and Rahardjo, H., 1993. Soil Mechanics for Unsatureted Soils. John Wiley and Sons: New York.

Linsey, R.K., Franzini, J.B., 1991. Teknik Sumber Daya Air Jilid II Edisi III. Erlangga. Jakarta.

Soedibyo. 1993. Teknik Bendungan. Pradnya Paramita: Jakarta.

Sosrodarsono, S and Takeda, K. 1981. Bendungan Tipe Urugan. Pradnya Paramita: Jakarta. 
